\title{
Corporate Social Responsibility as Innovation: Recent Developments in Lithuania
}

\author{
Rita Vilkè, Kaunas University of Technology
}

\begin{abstract}
The research is focused on the nexus between corporate social responsibility (CSR) and innovation. Scientific literature analysis, systematization and case study methods were applied. Aiming to clarify the interconnectivity of key terms and perspectives i.e., the nexus between CSR and innovation, the research is providing an overview of core issues and definitions in scientific discourse and practice. Based on that recent developments in Lithuania are analyzed from the systemic point of view taking into account the general innovation policy and CSR-driven initiatives. Research results show, that CSR-driven innovation from organized and systemic perspective are considered being at their initial phase throughout the country as in most cases companies lack systemic approach towards CSR. Therefore CSR might be considered as innovation in Lithuania, however further developments are essential.
\end{abstract}

Keywords - Corporate social responsibility (CSR), innovation, CSR-driven innovation.

\section{INTRODUCTION}

Modern companies in globalized world have already recognized corporate social responsibility (hereinafter referred as CSR) being a driver for innovations. The very first issue of social responsibility to be demanded from business was brought by Howard R. Bowen in his book "Social Responsibilities of the Businessman" [1] in the early fifties of past century. Later Carroll and Shabana state that Bowen's book is "noticeably ahead of its time, by at least a decade, but it came to shape significantly future thought on the subject" [2]. Notably argued by Milton Friedman's famous article "The Social Responsibility of Business is to Increase its Profits" [3] these ideas shortly turned into the great surge of respective debates on CSR throughout the world. Midttun states, that as a central business agenda CSR has emerged developing into a business megatrend with a global outreach [4].

The most general meaning of CSR is organization's acting voluntarily and beyond the law to achieve social and environmental objectives in its daily activities. Therefore CSR concerns the responsibility of various business, public and NGO entities for their impact on society. The European Commission (the Commission) defined CSR in its last policy Communication on CSR in 2006 as "a concept whereby companies integrate social and environmental concerns in their business operations and in their interaction with their stakeholders on a voluntary basis" [5]. Ideally, CSR is a winwin scenario, whereby companies increase their profitability and society benefits at the same time. Aiming to fully meet their social responsibility, businesses, as lately suggested by the Commission, "should have in place a process to integrate social, environmental, ethical, human rights and consumer concerns into their business operations and core strategy in close collaboration with their stakeholders" [6].

Within the past decades political debate, scientific evidence and corporate practices found CSR and innovation having significant impact on each other [4]-[8]. In its Communication to re-launch the Lisbon Strategy in 2005, the Commission stated that CSR "can play a key role in contributing to sustainable development while enhancing Europe's innovative potential and competitiveness" [9]. The Commission states, that a strategic approach to CSR can bring benefits in terms of risk management, cost savings, access to capital, customer relationships, human resource management, and innovation capacity. In either case, CSR requires engagement with internal and external stakeholders, therefore it enables enterprises to better anticipate and take advantage of fast changing societal expectations and operating conditions. Consequently it can drive the development of new markets and create opportunities for growth. Many companies across Europe have already recognized (most evident - throughout the economic crisis) how CSR-driven practices built long-term employee, consumer and citizen trust as a basis for sustainable business models. Therefore, higher level of trust in turn helps to create an environment in which enterprises can innovate and grow.

Concerning the definition of innovation, all new combinations are based upon the application of any particular innovation type, as distinguished by Schumpeter: new products, new methods of production, new sources of supply, the exploitation of new markets and new ways to organize business [10]. In this case most of the focus has been on the new ways to organize business. The social context of innovation drives new methods for alliances; accelerates joint venturing, deals with flexible work hours, and, indeed, has a significant contribution towards buyers' purchasing power.

Nowadays social innovations are disclosed in many forms worldwide. Matten et al. propose that innovation and the application of new technological options by the private sector are increasingly perceived as having fundamental implications for consumption choices and living standards of individuals across the globe [7]. Thus a discussion of innovative CSR brings together two terms of CSR and innovation that clearly have an impact on each other [11].

Consumption patterns are shaped, and lately the design of profitable product or services should not only prove beneficiary for the surrounding environment and society but actually change people's quality of life in a fundamental way more often. Through concepts such as design for environment [12] or sustainable design [13], innovative solutions to product 
and process design can contribute to the reduction of the social and environmental externalities of economic activity.

Thus, there is enough evidence around the world to prove that CSR-driven innovation results in increase in company's growth and competitiveness in a sustainable manner.

\section{NEXUS BETWEEN CSR AND INNOVATION}

Within the past decades scientific debate and corporate practices found CSR and innovation having significant impact on each other [4], [7], [8], [14] - [16].

The research of CSR-driven innovation in literature, proposed by Hockerts et al. in the study [15], found four overlapping schools of thought: corporate social innovation; bottom of the pyramid innovation; eco-innovation; and social entrepreneurship.

Lately particular additional insights regarding the nexus of CSR and innovation are proposed also from strategic CSR perspective by Midttun [4], [7].

Aiming to clarify the interconnectivity of key terms and perspectives, i.e., nexus of CSR and innovation, there is an overview of core issues provided in the following sections.

\section{A. Corporate Social Innovation}

The term corporate social innovation (CSI) was introduced in 1999 by Kanter from Harvard Business School [15]. He argued that "firms should use social issues as their learning laboratory for identifying unmet needs and for developing solutions that create new markets" [16, p. 286].

Hubert et al. in the report of "Empowering people, driving change: Social Innovation in the European Union" states, that in general, social innovation can be defined as a new response to pressing social demands, which affects the process of social interactions and is aimed at improving human wellbeing [18]. The suggestion made in the study is short and universal: "Social innovations are innovations that are social in both their ends and their means". And it is complemented by the following: "specifically, social innovations are defined as new ideas (products, services and models) that simultaneously meet social needs (more effectively than alternatives) and create new social relationships or collaborations. In other words they are innovations that are not only good for society but also enhance society's capacity to act".

Preuss states that social innovation can be defined as the development and implementation of new ideas (products, services and models) to meet social needs and create new social relationships or collaborations [17]. It represents new responses to pressing social demands which affect the process of social interactions.

Therefore social innovation stands for particular attitude towards CSR-driven innovations in its primary social aim in meeting most urgent social needs of society.

\section{B. Base of the Pyramid}

The Base of the Pyramid (is also often referred to as the "Bottom of the Pyramid, or just the BoP"') theory suggests that new business opportunities lie in designing and distributing goods and services for poor communities.
Prahalad and Hart were the first, who discussed the market fortune or, in other words, the potential of market at the Base of the pyramid (BoP) [19]. The perception that the bottom of the pyramid is not a viable market also fails to take into account the growing importance of the informal economy among the poorest of the poor, which by some estimates accounts for $40 \%-60 \%$ of all economic activity in developing countries [19]. Later on Prahalad proposed the whole idea of the BoP, which, as reviewed by famous entrepreneur Bill Gates, "offers an intriguing blueprint for how to fight poverty with profitability" [20].

It might put this point of view under criticism from the CSR perspective because of commercial focus. However, going deeper in, profitable markets might be created from the unmet needs of low-income populations. And let it be the profit motive, but at the same time the poor are provided with goods or services at their most urgent needs. Therefore, this meets the concerns on CSR regarding the way of earning profits, not spending them.

\section{Eco-Innovation}

The conceptual clarification of eco-innovation (developing a typology) based on an understanding of innovation dynamics was proposed by Kemp and Pearson. They state, that there exist different definitions of eco-innovation and environmental innovation [14]. While arguing whether an environmental aim should be a distinguishing feature of eco-innovation, they decided to base the definition of eco-innovation on environmental performance instead of environmental aim, because it is not the aim that is of interest but whether there are positive environmental effects related to its use.

Elkington and Burke, for example, argued that innovative business solutions could be used not only to improve the environment, but also to provide the basis for new business prospects overlooked by mainstream firms [21, p. 239]. This is quite often defined as, eco-preneurship, eco-design or clean technology venturing [22].

Finally, Kemp and Pearson propose the definition for ecoinnovation based on the OECD definition of innovation: "Ecoinnovation is the production, assimilation or exploitation of a product, production process, service or management or business method that is novel to the organization (developing or adopting it) and which results, throughout its life cycle, in a reduction of environmental risk, pollution and other negative impacts of resources use (including energy use) compared to relevant alternatives" [14].

As long as environmental issues are part of CSR concerns, eco-innovations have direct relation towards CSR-driven innovations.

\section{Social Entrepreneurship}

In its most general sense the concept of social entrepreneurship is understood as the business process of identified opportunities for sustainable public goods provision in solving most urgent societal problems. Therefore social entrepreneurship normally results in the creation of social enterprises, as well as hybrid organizations with binary characteristics, i.e., not-for-profit and for-profit. 
For instance, Schwab defines corporate social entrepreneurship as the transformation of socially and environmentally responsible ideas into products or services [23]. He states, that mainly corporate governance is more than the way in which a company is run, as it also overwhelms company's compliance with local and international laws, transparency and accountability requirements, ethical norms, environmental and social codes of conduct, thus addressing CSR to be the conjunctive paradigm.

As a conjunction, social entrepreneurship issues are a pathway through the CSR, and the outcome is global corporate citizenship which must be recognized in expressing the conviction - companies not only must be engaged with their stakeholders but are themselves stakeholders alongside governments and civil society. Thus social entrepreneurship stands in parallel with CSR-driven innovation.

\section{E. CSR-driven Innovations from Strategic Perspective}

CSR-driven innovation as object of the scientific interest from strategic management perspective was recognized in Midttun's works, e.g., in [4], [7]. Some of the central insights emerging from Midttun's explorative study are that CSRdriven innovation entails a number of specific possibilities and constraints [7]:

- allows a move beyond defensive and proactive CSR into a more rewarding synthesis between social and commercial concerns;

- introduces the paradigm of serving both societal and individual needs, thereby transcending the division between public and private goods;

- necessitates an alignment between micro-level business strategy and macro-level societal needs;

- creates new opportunities for finance, organization, marketing and regulation, and allows new dynamic alignments to drive learning investments, niche markets and product differentiation.

Midttun in his research [7] proposes three cases of CSRfocused innovation which represent a deeper CSR engagement than that present in the ordinary firm, stating the strategic CSR engagement to be at the heart of the core business model.

Thus overviewed interconnectivity of key terms and perspectives of CSR and innovation shows how CSR is found at the core of innovative business from different perspectives. It should be stated here, that in any case there are two major conditions for CSR-driven innovation: from innovations' aspect and from CSR aspect.

First, favourable innovation environment stands for the condition of CSR-driven innovation from innovations' aspect, i.e., the creation of an appropriate environment in a particular country for innovations in general is essential with the aim to develop CSR-driven innovation.

Second, from the CSR aspect the general recognition of CSR being an issue of importance for business, governments, NGOs, and society as a whole. CSR-driven innovation can be established even within societies which recognize core principles and values of CSR, and not necessary externalized literally. The core CSR issues might be recognized even by those public and private actors who do not call it CSR, but their actual activity stands for the essence of it. However, the latter context is quite complicated to investigate. Besides, this is not the direct object of the research in this article. Therefore, for the current stage of the article it is enough to state, that particular actual evidence might help define whether CSR is recognized in a particular organization, country, region, etc. This evidence is externalized for instance, under a particular CSR institutionalization stage (separate social activities versus organized, systemic developments, institutions, CSR programmes, etc.), particular standards (e.g., Social Accountability 8000, ISO 26000, OHSAS 18001, etc.), national and international initiatives (e.g., The Global Compact Networks, Responsible Business Awards, etc.) and others.

These two core conditions draw the general basis for further research on CSR as innovation developments in particular context, e.g., particular country. In the Lithuanian case the research proposes to investigate CSR as innovation from both aspects.

\section{CSR AS INNOVATION IN LITHUANIA}

Under the pressure of open market CSR has already started its journey in transition countries, including Lithuania. From the very beginning concerned with a number of desultory social activities performed by business and NGOs mostly, CSR begins to play an increasingly important role in a more focused and organized manner.

The observed scientific problem exists within the range of innovative social activities which has become increasingly focused on CSR. Therefore there is a room for discussion whether these developments are systemic and organized (favourable environment for innovations and institutionalized CSR) and might be considered as CSR-driven innovations in Lithuania.

\section{A. Overview of General Innovation Environment in Lithuania}

Ziegenbalg and Munteanu have described innovation policy development in Lithuania as "slightly shifting from public innovation support infrastructure development towards the creation of large business and R \& D partnership platforms, supported by the development of $\mathrm{R} \& \mathrm{D}$ projects and businesses and a systemic upgrade of the highest level qualifications for science and technology" [24, p. 7]. The analysis of the composition and funding levels of RTD and innovation policy revealed the core focus on the development of high technology areas, which is also specified in the Lithuanian knowledge-based economy vision. The huge problem of heavy reliance on public funds in innovation policy implementation was identified. Direct grants-based support schemes result in the limited policy impact to the selected entities. Thus the freedom of experimentation and larger numbers of businesses and individual entrepreneurs are restricted. Therefore the regulation-based improvements are vitally important in creating more favourable environment for social innovations and social entrepreneurship in the nearest future. 
The most notable trend of business and public sector management from CSR-driven innovation perspective is the increasing consumption of work organization in the form of projects and programs. In Lithuania the role of innovative project management in both national and individual organizations, strategy formulation and implementation is seen quite clearly. From the analysis of "The Long-term Development Strategy" [25] and annual reports on the implementation of various fields it is evident in many areas of the strategy implemented in the framework of innovative programs and projects.

The important CSR-driven innovation role is mainly caused by EU support. The EU structural support for Lithuania for 2007-2013 [26], which came from the European Social Fund, European Regional Development Fund and the Cohesion Fund was nearly 7 billion euros, while all EU support for Lithuania was about 10 billion euros. EU Structural Funds support provided to Lithuania for 2007-2013 was implemented according to the approved strategy and action programs to implement the strategy: Human resources development programme - for the mobilization of people of working age of Lithuania, because the investment in Lithuanian people's knowledge, skills, activity and enterprise guaranteed the long-term economic growth $-13.8 \%$ of EU Structural support; The economic growth action programme provided for the maximum support resources $-45.72 \%$; it was very important that as much as $10 \%$ of the provided funds were for economic growth and competitiveness for research and technological development; Technical assistance of action programme - was a special action program for administration of thematic programs of the action. This program received $1.4 \%$ of EU structural funds support.

The administration of EU support programs is relatively complicated, funds system is cumbersome, difficult to understand and assimilate, program objectives and the rules are different for each program. Thus the use of EU support in the field of CSR-driven innovation highly depends on certain specialized skills and knowledge.

These perspectives closely correlate with the main objectives of innovation development in Lithuanian National Innovation Strategy for the years 2010 - 2020 [27]:

- to increase Lithuania's integration into global markets ("Lithuania without borders");

- to develop a creative and innovative society;

- to develop various innovations;

- to implement a systematic approach to innovation.

In 2010, the European Commission sponsored the implementation of pivotal research in the field of innovation, namely "Comprehensive analysis of programs and initiatives in Lithuania that assist the Collaboration between science and SMEs" [28]. Several important aspects were stated directly regarding $\mathrm{R} \& \mathrm{D}$ and innovation development issues in Lithuania.

First, due to the small country $\mathrm{R} \& \mathrm{D}$ policies are centralized; only two institutions are responsible for design (Ministry of Economy and the Ministry of Education and
Science) and one institution for implementation (Lithuanian Innovation Centre) of R \& D policies; the advantage is that these institutions are national, not regional.

Second, the key tool of the R \& D policy is block funding in Lithuania; research in universities is financed by the state budget once a year in lump sums; low effectiveness in the use of these resources is due to the direct funding without respective competitive base.

Finally, the relatively low business expenditure for R \& D normally results in a very low collaboration level between the industry and academia in Lithuania.

Despite that, the results of innovative activity in Lithuania have to achieve the general targets declared at the European level and to ensure a strong competitive position in global markets for Lithuania.

In the forthcoming decade, Lithuania has to create an economy based on innovations, new technologies and qualified human resources [27]. In 2010, the Summary Innovation Index (SII) of Lithuania was 0.227 , while the EU27 average equalled 0.516. Taking into account the recent trends in the Lithuanian SII and the economic, social and political situation, it is expected that Lithuanian SII will be 0.325 in 2015, reaching the EU-27 average observed in 2008 by 2020 [29].

\section{B. Overview of General CSR Recognition in Lithuania}

Great progress has been made in CSR endorsement in old EU member states. However, the integration of CSR means and values into new EU member states is a more complicated, but not impracticable, process.

Lithuania joined the European Union on 1 May 2004, and in parallel, initiatives of CSR ideas gained a new phase with the creation of the National Network of Socially Responsible Enterprises. The Network was officially launched in April 2005 as a voluntary initiative by the Group of Initiative, which was formed during the First International Conference on the United Nations Global Compact and the Corporate Social Responsibility Concept in November 2004 with the purpose of exchanging knowledge, experience and innovations and organizing joint learning forums, thereby improving business strategies and implementing joint projects for the benefit of society.

Starting with some 11 enterprises in 2004, now the National Network of Responsible Business, as well as the United Nations Development Programme in Lithuania (UNDP Lithuania) comprises 110 enterprises; most of them are members of the UN Global Compact Initiative [30]. The Global Compact was launched at the UN Headquarters in New York on 26 July 2000 [31], and today hundreds of business companies, academic institutions, civil society organizations, government and other public institutions from all around the world are engaged in reaching the advancement in four areas (human rights, labour rights, environment, anti-corruption) emphasized by ten principles of Global Compact.

However, the number of National Socially Responsible Business Network member-enterprises has not reached even $0.8 \%$ of the total number of companies operating in Lithuania; 
according to the Lithuanian Statistics Database of Indicators, nearly 66 thousand companies were operating at the beginning of 2013 and only 110 companies were members of Socially Responsible Network.

The most active companies in the field of CSR were large enterprises, which were mainly based on foreign capital (e.g., TEO LT); in contrast, small and medium enterprises were not very active in CSR.

From the most general perspective, CSR is still quite a new paradigm in Lithuania. Several companies practice CSR, but there are still no consolidated efforts at the country level, thus it is only the very beginning of an understanding of the importance of CSR. Only since that period has CSR appeared on the agenda of state institutions especially after the request from EU headquarters for the report on CSR promotion in Lithuania. All activities related to CSR are mainly coordinated by UNDP Lithuania and the Ministry of Social Security and Labour, with quite a few sense of dialogue between them on basic CSR endorsement issues.

The Ministry of Social Security and Labour of the Republic of Lithuania, responsible for CSR-related state policy development in Lithuania, on 22 December 2005 approved the Action Plan on Measures Promoting Corporate Social Responsibility in 2006 - 2008 (hereinafter referred as "Action Plan 1" [32]. The vision of CSR development in Lithuania developed in Action Plan 1 encompassed:

- competitive companies that change according to the conditions in global economies;

- safe, clean environment;

- strong social cohesion;

- transparent and ethical business practices.

The priority of the country in CSR set by the Action Plan 1 was to encourage the development of CSR while cooperating with economic, social and international partners.

By implementing Action Plan 1 in 2006-2008 [33] the Ministry of Social Security and Labour of the Republic of Lithuania and the UNDP initiative undertook a baseline analysis of the current CSR situation in Lithuania and CSR promoting and interfering legal factors, concluding with CSR development recommendations.

These studies showed that CSR promotion vehicles are often developed and implemented in isolation one from another in Lithuania. Also, lack of inter-institutional cooperation and coordination, inadequate institutional capacity and lack of a management framework for the implementation and coordination of CSR implementation were observed. In other words, the concluding results showed the lack of coordination and communication among the institutions and highlighted the non-existence of CSR departments; no united CSR administration has been created. One of the measures to be introduced under Action Plan 1 was the establishment of a CSR acknowledgement system by the Ministry in the form of an Annual CSR Award [33]. Consequently, the first awards ceremony was organized in the beginning of 2008 which continues annually.

Following these circumstances, the five-year National Corporate Social Responsibility Development Program in
2009 - 2013 (hereinafter referred as "National CSR Program") was prepared; in parallel the Action Plan on Measures Promoting Corporate Social Responsibility in 2009-2011 (hereinafter referred as "Action Plan 2" [34]) was approved on 12 January 2010.

The main purpose of the National Program for 2009 - 2013 was to create friendly environment for the development of CSR in Lithuania and to encourage companies to implement CSR principles in their activities through achieving the three main goals.

By approving the National CSR Program the Government of the Republic of Lithuania admitted legally that socially responsible business met the welfare expectations of society and was beneficial for social and economic development. It was expected that by the end of 2013 the main three goals set in the National CSR Program and discussed above would be achieved.

However, there was no emphasis on public sector roles in promoting CSR ideas among society in the final version of the National CSR Program, although The Ministry of the Interior of the Republic of Lithuania identified public sector roles and suggested corrections in its responses to the National CSR Program Project. Nevertheless, these corrections were ignored.

\section{CSR-Driven Innovations in Lithuania}

CSR-driven innovation from organized and systemic perspective is quite evident in the results achieved by UNDP Lithuania implemented EU sponsored project No. VP1-1.1SADM-03-V-02-001 called "Gateway: Corporate Social and Environmental Innovations", during the period of the years 2010 - 2013 [35]. In general, the project aimed at creating the necessary conditions for the development of CSR in Lithuania and at encouraging companies to apply these principles in everyday life. This project might be considered as CSR-driven innovation. It was unique and innovative and at the same time addressed the complexity of constraints to the development of CSR-low prevalence of CSR in business and low understanding of its benefits. The project helped to create more than 20 common initiatives with the participation of 20 NGOs and over 50 businesses.

One of the most annually nominated for Lithuanian Responsible Business Awards foreign capital Telecommunication Company is "TEO LT". This company participated in three initiatives with NGOs during the implementation period of the project [35]. Firstly, "TEO LT" employees were trained how to interact with the disabled in the joint activity with Charity and Support Fund "Algojimas". Secondly, the joint activity with public institution "Alive Lithuania" resulted in the initiative "Don't buy water in plastic bottles", which was presented and discussed with "TEO LT" staff. And finally, the pilot project of student internships with public institution "School of Success": during the introductory events of the project one student got internship at "TEO LT". Student internship initiatives have been successfully developing till now.

In line "TEO LT" subsidiary "Lintel" also participated in the above mentioned project partnership initiative together 
with public enterprise Responsible Business and Mentoring Institute with the aim to implement welfare program for the "Lintel" staff [36]. The initiative focused on relations' improvement among employees, psychological climate, employee motivation enhancement, satisfaction and social security.

The paper presented only one particular example of recent CSR-driven innovations in Lithuania. It is quite important to state, that the implemented project [35] is one of good practice examples of systemic and focused CSR-driven innovations in Lithuania. However it should be hardly considered as organized practice as a whole.

\section{CONCLUSION AND DISCUSSION}

Within the past decades political debate, scientific evidence and corporate practices found CSR and innovation having significant impact on each other. Ideally, CSR is a win-win scenario, whereby companies increase their profitability and society benefits at the same time.

During the last decade CSR has been increasingly recognized as being a driver for innovations. In this case, most of the focus has been on the new ways to organize business. The social context of innovation drives new methods for alliances; accelerates joint venturing, deals with flexible work hours, and has a significant contribution towards buyers' purchasing power. Nowadays social innovations are disclosed in many forms worldwide

The research of CSR-driven innovation in the literature is referred under four overlapping schools of thought: corporate social innovation, bottom of the pyramid innovation, ecoinnovation, and social entrepreneurship. Lately, particular additional insights regarding the nexus of CSR and innovations are proposed also from strategic CSR perspective.

In any case there are two major conditions for CSR-driven innovations: from innovations' aspect and from CSR aspect. From the innovations' aspect favourable innovation environment stands for condition of CSR-driven innovation. From CSR aspect, CSR-driven innovations can be established even within societies which recognize core principles and values of CSR, and not necessary externalized literally. These two core conditions draw the general basis for further research on CSR as innovation developments in particular context, e.g., in particular country.

Research of "Lithuanian Case for CSR as Innovation" proposes particular insights from both - innovation's and CSR aspects. The overview of general innovation environment in Lithuania shows that the role of CSR-driven innovation is mainly accelerated by EU support. The innovative activity in Lithuania has to achieve the general targets declared at the European level and to ensure a strong competitive position in global markets for Lithuania. Therefore the innovation environment is considered to be favourable for CSR-driven innovations from the latter aspect.

The overview of general CSR recognition in Lithuania shows that CSR promotion vehicles which were former developed and implemented in isolation one from another and had lack of coordination and communication among the institutions have been organized under National Corporate Social Responsibility Development Program; therefore this is considered to be legally admitted that socially responsible business meets the welfare expectations of society and is beneficial for social and economic development. Therefore CSR environment is considered as developing.

CSR-driven innovation from organized and systemic perspective throughout the country might be considered as being at its initial phase as in most cases companies lack systemic approach towards CSR. Only a few focus institutionalization in terms of developed CSR programs, strategies and appropriate structures. Nevertheless it should be stated that the existing good practice examples, such as consolidated efforts between UNDP Lithuania and the Ministry of Social Security and Labour of the Republic of Lithuania are focused activities (National Responsible Business Awards, lately implemented project, etc.) regarding organized CSR-driven innovations at national level.

\section{REFERENCES}

[1] Bowen, H. R., "Social Responsibilities of The Businessman," Harper \& Brothers, New York, 1953.

[2] Carroll, A. B. and Shabana, K. M., "The Business Case for Corporate Social Responsibility: A Review of Concepts, Research and Practice," International Journal of Management Reviews, vol. 12, no. 1, pp. 85-105, 2010. http://dx.doi.org/10.1111/j.1468-2370.2009.00275.x

[3] Friedman, M., "The Social Responsibility of Business Is to Increase Its Profits," New York Times Magazine, Sep. 13, 1970. [Online]. Available: http://www.colorado.edu/studentgroups/libertarians/issues/friedman-socresp-business.html [Accessed: Sep.19, 2013].

[4] Midttun, A., "CSR and innovation, compatibility or contradiction? Towards a dynamic reinterpretation of CSR," The Norwegian School of Management, CSR paper 3, 2006.

[5] European Commission, "Implementing the Partnership for Growth and Jobs: Making Europe a Pole of Excellence on CSR”, Brussels, 22.3.2006 $\operatorname{COM}(2006) 136$ final. [Online]. Available: http://eur-lex.europa.eu/ LexUriServ/LexUriServ.do?uri=COM:2006:0136:FIN:EN:PDF [Accessed: Sep. 11, 2013].

[6] European commission, "A renewed EU strategy 2011-14 for Corporate Social Responsibility. Communication from the Commission to the European parliament, the Council, the European Economic and Social Committee and the Committee of the regions". Brussels, 25.10.2011 $\operatorname{COM}(2011) 681$ final [Online]. Available: http://eur-lex.europa.eu/ LexUriServ/LexUriServ.do?uri=COM:2011:0681:FIN:EN:PDF

[Accessed: Sep. 19, 2013].

[7] Matten, D., Crane, A. and Moon, J., "Corporate Responsibility for Innovation - A Citizenship Framework", in Hanekamp, G. (ed) Business Ethics for Innovation, Springer, 2007, pp. 63-88. http://dx.doi.org/10.1007/978-3-540-72310-3 5

[8] Midttun, A. (eds), "Strategic CSR Innovation: Serving Societal and Individual Needs," Research Report 2/2009, BI Norwegian School of Management. [Online]. Available: http://web.bi.no/forskning/papers.nsf/ 0/2893041b91f4e4fcc12575690042d6d9/\$FILE/2009-02-midttun.pdf [Accessed: Sep. 13, 2013].

[9] European Commission, "Growth and Jobs: Relaunch of the Lisbon strategy" Brussels, 22 and 23 March 2005 [Online]. Available: http://www.consilium.europa.eu/uedocs/cms_data/docs/pressdata/en/ec/ 84335.pdf [Accessed: Sep. 19, 2013].

[10] Schumpeter, J., "The theory of Economic Development," Oxford University Press, London, 1934, pp. 231-232.

[11] Lutz, P. „Barriers to innovative CSR: The impacts of organisational learning, organisational structure and the social embeddedness of the firm" in Innovative CSR: From Risk Management to Value Creation. Greenleaf Publishing Limited, 2010, pp. 331-351. [Online]. Available: http://dx.doi.org/10.9774/GLEAF.978-1-907643-26-2_17 [Accessed: Sep. 9, 2013].

[12] Fiksel, J., "Design for environment: creating eco-efficient products and processes," McGraw-Hill, 1996. 
[13] Carrano, A. L. and Thorn, B. K., "A Multidisciplinary Approach to Sustainable Product and Process Design", Journal of Manufacturing Systems, vol. 24, no. 3, pp. 209-214, 2006. http://dx.doi.org/10.1016/S0278-6125(06)80010-5

[14] Kemp, R. and Pearson, P., "Final report MEI project about measuring ecoinnovation", 2007. [Online]. Available: http://www.oecd.org/env/ consumption-innovation/43960830.pdf [Accessed: Sep. 21, 2013].

[15] Hockerts, K., Morsing, M., Eder-Hansen, J. et al., "CSR-Driven Innovation: Towards the Social Purpose Business," Jan. 2009. [Online]. Available: http://www.academia.edu/2837447/CSR-driven_Innovation_Towards_the_ Social_Purpose_Business [Accessed: Sep. 14, 2013].

[16] Louche, C., Idowu, S., Filho, W. (eds.), "Innovative CSR- From Risk Management to Value Creation," Greenleaf Publishing, 2010. [Online] Available: http://books.google.lt/books?isbn=1907643265 [Accessed: Sep. 21, 2013].

[17] Preuss, L., "The Contribution of Purchasing and Supply Management to Ecological Innovation“, International Journal of Innovation Management, vol. 11, no. 4, pp. 515-537, 2007. http://dx.doi.org/10.1142/S1363919607001850

[18] Hubert, A. etal., "Empowering people, driving change: Social Innovation in the European Union. Luxembourg: Publications Office of the European Union,” 2011. [Online]. Available: http://ec.europa.eu/bepa/ pdf/publications_pdf/social_innovation.pdf [Accessed: Sep. 19, 2013].

[19] Prahalad, C. K. and Hart, S. L., "The Fortune at the Bottom of the Pyramid," Booz Allen Hamilton Inc., 2002. [Online]. Available: http://www.cs.berkeley.edu/ brewer/ict4b/Fortune-BoP.pdf [Accessed Sep. 21, 2013].

[20] Gates B., "Review from the Back Cover" in The Fortune at the Bottom of the Pyramid: Eradicating Poverty Through Profits. Wharton School Publishing, 2004. [Online]. Available: http://www.amazon.com/FortuneBottom-Pyramid-Eradicating-Poverty/dp/0131467506 [Accessed: Sep. 21, 2013].

[21] Elkington, J. and Burke, T., “The Green Capitalists,” Gollancz, 1989. p. 239.

[22] Fussler, C. and James, P., "Driving Eco-Innovation: A Breakthrough Discipline for Innovation and Sustainability," Pitman Publishing: London, 1996.

[23] Schwab, K., "Global Corporate Citizenship. Working with Governments and Civil Society". Foreign Affairs, vol. 87, no. 1, pp. 107-118, 2008.

[24] Ziegenbalg, C., Munteanu, O. (eds.), "Comprehensive analysis of programmes and initiatives in Lithuania that assist the Collaboration between science and SME," MaPEeR SME Report, 2010. [Online]. Available: http://caesie.org/s/Lithuania_programme_report.pdf [Accessed: Sep. 16, 2013].

[25] "The Long-term Development Strategy of Lithuania," approved by the Seimas of the Republic of Lithuania on 12 November 2002, Resolution No.IX-1187. State News, No.60-2424, 2002. Government of the Republic of Lithuania, Vilnius.

[26] "EU Structural Support for Lithuania in 2007-2013," [Online]. Available: http://www.euro.lt/en/lithuanias-membership-in-the-eu/eu-structural-support/ [Accessed: Sep. 16, 2013].

[27] "Lithuanian National Innovation Strategy for the year 2010-2020," [Online]. Available: http://www.ukmin.lt/lt/veikla/veiklos_sritys/ino/ LIS_ENG.doc [Accessed: Sep. 17, 2013].
[28] Report conducted for the European Commission, Research DirectorateGeneral, under FP7-SME-2009-1, SP4-Capacities: [Online]. Available: http://mapeer-sme.eu/en/ /media/MaPEer-SME/DocumentLibrary/RTD\% 20programmes/Lithuania_programm_report [Accessed: Sep. 17, 2013].

[29] Innovation Union Scoreboard 2010, "The Innovation Union's performance scoreboard for Research and Innovation," Feb. 1, 2011. [Online]. Available: http://www.proinno-europe.eu/inno-metrics/page/ innovation-union-scoreboard-2010 [Accessed: Sep. 19, 2013].

[30] "United Nations Global Compact Initiative - Lithuania," [Online]. Available: http://www.unglobalcompact.org/NetworksAroundTheWorld/ local_network_sheet/LT.html [Accessed: Sep. 29, 2013].

[31] Corporate Citizenship in the World Economy, "The Principles of the Global Compact," [Online]. Available: http://www.un.org/Depts/ptd/ about-us/un-global-compact [Accessed: Sep. 29, 2013].

[32] Government of the Republic of Lithuania, "Action plan on measures promoting corporate social responsibility in Lithuania in 2006-2008", State News, No. 2-28, 2006. Government of the Republic of Lithuania, Vilnius.

[33] Dubee, K. and Rugiero, J. D., "Overview of CSR award systems in Europe and advice on establishment of Government Award system in Lithuania. Daxam Sustainability Services and UNDP Lithuania," Vilnius, 2007.

[34] Government of the Republic of Lithuania, "National Corporate Social Responsibility Development Program in 2009-2013 and Action Plan on Measures Promoting Corporate Social Responsibility in Lithuania in 2009-2011", State News, No. 8-368, 2010. Government of the Republic of Lithuania, Vilnius.

[35] Project "Gateway: Corporate Social and Environmental Innovations," Project No. VP1-1.1-SADM-03-V-02-001 [Online]. Available: http://www.esparama.lt/en/projektas?id=22287 [Accessed: Sep. 23, 2013].

[36] "TEO LT in Brief," [Online]. Available: http://www.teo.lt/en/press/2273 [Accessed Sep. 30, 2013].

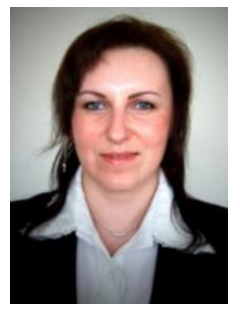

Rita Vilkè received the Master's degree in Public Administration in 2005 and the $\mathrm{PhD}$ degree in Social Sciences, Management and Administration in 2011.

She is currently an Associate Professor with the Faculty of Economics and Management, Kaunas University of Technology, Kaunas, Lithuania. Her previous work experience includes scientific research work, lecturing, work in business and public sector. Her research interests include corporate social responsibility, corporate governance, modern management systems, quality management, strategic planning, entrepreneurship, small and medium business development.

She is a member of Social Responsibility Research Network, Eurasia Business and Economics Society, Lithuanian Young Scientists Organization. She has received the Emerald Literati Network Award "Highly Commended Paper 2012" for the article "CSR development problems in Lithuania: evaluation of promoting and hindering factors", published in "Social Responsibility Journal" in 2011.

Address: Donelaičio Str. 20-507, LT-44239, Kaunas, Lithuania;

E-mail: rita.vilke@ktu.lt 